\title{
A survey of the Scyphozoa and Cubozoa (Cnidaria, Medusozoa) from the Ceará coast (NE Brazil)
}

\author{
André Carrara Morandini ${ }^{1,3}$, Marcelo de Oliveira Soares², Helena Matthews-Cascon² \& Antonio Carlos Marques ${ }^{1}$
}

Biota Neotropica v6 (n2)-http://www.biotaneotropica.org.br/v6n2/pt/abstract?inventory+bn01406022006

\author{
Date Received 05/06/2005 \\ Revised 03/15/2006 \\ Accepted 05/01/2006
}
${ }^{1}$ Departamento de Zoologia, Instituto de Biociências, Universidade de São Paulo, C.P. 11461, 05422-970
São Paulo, SP, Brazil
${ }^{2}$ Laboratorio de Invertebrados Marinhos, Departamento de Biologia, Centro de Ciências, Campus do Pici, Universidade Federal do Ceará, C.P. D-3001, 60455-760 Fortaleza, CE, Brazil ${ }^{3}$ corresponding author/autor para correspondência

e-mails: acmorand@usp.br, andre.morandini@gmail.com, bio marcelo@yahoo.com.br, hmc@ufc.br, marques@ib.usp.br

\begin{abstract}
Morandini, A.C.; Soares, M.O.; Matthews-Cascon, H. and Marques, A.C. A survey of the Scyphozoa and Cubozoa (Cnidaria, Medusozoa) from the Ceará coast (NE Brazil). Biota Neotrop. May/Aug 2006 vol. 6, http://www.biotaneotropica.org.br/ v6n2/pt/abstract?inventory+bn01406022006. ISSN 1676-0611
\end{abstract}

Most of the scyphozoans and cubozoans recorded for the Brazilian coast are presumed to be distributed over the entire coastline, but little information on precise records is available. This paper presents the first published records for the Ceará state (northeastern region) of the cubozoan Chiropsalmus quadrumanus, and the scyphozoans Chrysaora lactea, Linuche unguiculata (polyp), Lychnorhiza lucerna, Nausithoe sp. (polyp), Phyllorhiza punctata, and Stomolophus meleagris. The medusoid species have been known by local fishermen and non-specialists for a long time in the area.

Key words: Scyphomedusae, Cubomedusae, jellyfish, Chirodropidae, Coronatae, Semaeostomeae, Rhizostomeae

\section{Resumo}

Morandini, A.C.; Soares, M.O.; Matthews-Cascon, H. and Marques, A.C. Levantamento de Scyphozoa e Cubozoa (Cnidaria, Medusozoa) do litoral do Ceará (NE do Brasil) Biota Neotrop. May/Aug 2006 vol. 6, no. 2, http:// www.biotaneotropica.org.br/v6n2/pt/abstract?inventory+bn01406022006. ISSN 1676-0611

A maioria das cifomedusas e cubomedusas registradas para o litoral brasileiro é presumivelmente distribuída por toda a costa; porém poucos registros precisos estão disponíveis. Este estudo apresenta os primeiros registros publicados para o estado do Ceará (região Nordeste) da cubomedusa Chiropsalmus quadrumanus, e dos cifozoários: Chrysaora lactea, Linuche unguiculata (pólipo), Lychnorhiza lucerna, Nausithoe sp. (pólipo), Phyllorhiza punctata and Stomolophus meleagris. As espécies de medusas são conhecidas de longa data por pescadores locais e não-especialistas no grupo.

Palavras-chave: Cifomedusas, cubomedusas, águas-vivas, Chirodropidae, Coronatae, Semaeostomeae, Rhizostomeae

http://www.biotaneotropica.org.br 


\section{Introduction}

Medusozoan cnidarians are important ecologically and economically (e.g. Mills 2001). The medusozoan fauna is fairly well known in Brazilian waters (see list in Migotto et al. 2002). Concerning non-hydrozoan medusozoans, the fauna includes 22 species of Scyphozoa, four of Cubozoa, and one of Staurozoa (Migotto et al. 2002, Morandini 2003). Marques et al. (2003) discussed the distribution of medusozoans from a geographical and historical perspective, and highlighted the lack of knowledge in some areas, toward which studies should be focused. The Northeast region of Brazil is among the poorest known areas for both planktonic and benthic medusozoans. The species listed herein are new records for the Ceará coast, although most of them are inside the distributional range of the species or known for a long time by local fishermen and marine biologists not specializing on the group.

Recently, the Brazilian Federal Government (MMACNPq) has supported efforts to improve the basic faunistic knowledge in "priority areas" through the PROBIO program (Project for conservation and sustainable management of Brazilian biological diversity). We have collaborated in the study of the "Marine biota of the west coast of Ceará". Ceará state is located in the northern part of the Northeast region of Brazil (see Fig. 1). Its coastline is ca. $590 \mathrm{~km}$ long and included several different habitats: sandy beaches, dunes, rocky shores, estuarine areas, mangroves, reefs and beach rocks (Smith \& Morais 1984). Environmental impacts on the coast have been increased in recent decades by tourism, harbor building, algae exploration, etc. The aim of this paper is to increase knowledge on the distribution of scyphozoans and cubozoans on the northeastern Brazilian coast, especially regarding Ceará state.

\section{Materials and Methods}

We studied preserved specimens of the Invertebrate collection of the Universidade Federal do Ceará (UFC), and specimens collected on November 2002 and October 2003. Specific collection data is listed in the "Material examined" of each species. Specimens of all species were deposited in the cnidarian collection of the Museu de Zoologia da Universidade de São Paulo (MZUSP). Freshly collected specimens were preserved in $4 \%$ formaldehyde solution in sea water and observed under stereomicroscope; measurements were taken with a plastic ruler or under stereomicroscope. Identification and classification followed Kramp (1961) and Mianzan \& Cornelius (1999). References to each species include only those that specifically concern Brazilian material.

\section{Results and Discussion}

\section{Account of species}

Phylum Cnidaria Verrill, 1865 -Sub-phylum Medusozoa Petersen, 1979

Class Cubozoa Werner, 1975-Order Cubomedusae Haeckel, 1880

Family Chirodropidae Haeckel, 1892

Genus Chiropsalmus L. Agassiz, 1862

Chiropsalmus quadrumanus (F. Müller, 1859)

Tamoya quadrumana F. Müller 1859: 4-11; Pl. II figs 18-25, Pl. III figs 26-29.

Chiropsalmus quadrumanus: L. Agassiz 1862: 174.

References.- Müller (1859: 1-12); Vannucci (1954: 120-122; 1957: 594-595); Mianzan \& Cornelius (1999: 533); Migotto et al. (2002: 22); Morandini et al. (2005: 283).

Material examined.- Brazil, Ceará State: 43 young medusae with beginning of gonads, Fortaleza, Meireles beach, 4\% formaldehyde solution preserved, fishing trawl, 1990-1992, leg. H. Matthews-Cascon, det. A.C. Morandini (MZUSP 468, 2 specimens).

Description.- Umbrella cuboid with rounded corners, nearly as high as wide, height $2.0-4.5 \mathrm{~cm}$, width $3.5-5.0 \mathrm{~cm}$. Exumbrellar surface in some specimens with small nematocyst warts. Velarium with numerous branching canals. Four rhopalia on sides of the bell, up from margin, with triangular niches. Four palmate pedalia with 5-7 tentacles, each tentacle arising from its own digitate projection. Pedalial canal with small diverticulum. Manubrium with 4 lips. Wide stomach with 4 pouches, each one with 2 smooth finger-shaped sacculi hanging on subumbrelar cavity, longer than manubrium. Four developing gonads. Coloration pale white (preserved material).

Systematic remarks.- The genus Chiropsalmus has 4 species: C. buitendijki Horst, 1907 (Indonesia, India); C. quadrigatus Haeckel, 1880 (Indian Ocean, Philippines, Australia, Singapore); C. quadrumanus (Atlantic); and C. zygonema Haeckel, 1880 (Argentina). Identification of species of the genus is cumbersome; this is true even at the family level (Cornelius 1997). There is no revision of the group hitherto, and the species are mainly separated by their geographical ranges (Kramp 1961).

Distribution.-Brazil: From Santa Catarina to Amapá states. Elsewhere: Atlantic coast of America.

Diagnostic features.- Finger-shaped gastric sacculi longer than the manubrium, but not reaching the margin of umbrella. Restricted to Atlantic waters. 
Class Scyphozoa Goette, 1887- Order Coronatae Vanhöffen 1892

Family Linuchidae Haeckel, 1880

Genus Linuche Eschscholtz, 1829

Linuche unguiculata (Swartz, 1788)

Medusa unguiculata Swartz 1788: 199-200; Pl. VI fig. 1a-e. Linuche unguiculata: Eschscholtz 1829: 91.

Linantha lunulata Haeckel 1880: 494; Pl. XXIX figs 1-3.

Linerges mercurius Haeckel 1880: 495; Pl. XXIX figs 4-6.

Linerges pegasus Haeckel 1880: 495-496.

Liniscus cyamopterus Haeckel 1880: 497-498.

Liniscus ornithopterus Haeckel 1880: 497.

Liniscus sandalopterus Haeckel 1880: 497.

Linuche vesiculata Haeckel 1880: 499.

Stephanoscyphus komai Leloup 1937: 66 (polyp stage); fig. 42 .

References.- Silveira \& Morandini (1998a; 1998b); Mianzan \& Cornelius (1999: 535-536); Migotto et al. (2002: 22); Morandini et al. (2005: 283).

Material examined.- MZUSP 469: Brazil, Ceará State, off Paracuru county (3858’30,7" W, 0258’01,4" S), 43 m depth, 10.xii.1999, 3 colonies, 70\% ethanol solution preserved, leg. I. Braga, det. A.C. Morandini. - MZUSP 470: Brazil, Ceará State, Trairi county, Fleixeiras (39 $25^{\prime}$ 'W, 0322' S), 1 m depth, 03.Nov.2002, one scyphistoma, 70\% ethanol solution preserved, leg. E.F. Rabelo, det. A.C. Morandini.

Description.- Colonial scyphistomae, with polyps connected by stolonal scyphorhiza. Periderm tube light brown, almost isodiametrical from base to aperture. Tubes 3.5-6.0 mm in length. Tubes with up to two internal cupshaped cusps with secondary cusps on the edge, not aligned to each other. Tubes found growing on calcareous debris, and near a zoanthid species (Isaurus tuberculatus Gray, 1828).

Systematic remarks.- The polyp stage of L . unguiculata was first reported in Brazil by Silveira \& Morandini (1998a; 1998b), from the north coast of São Paulo State. Polyps and medusae are known to occur in the Caribbean (Ortiz-Corp's et al. 1987).

Distribution.- Brazil: Rio de Janeiro, Santa Catarina and São Paulo states (Silveira \& Morandini 1998a). New record for Ceará state, first record to northeastern Brazil. Elsewhere: Western tropical Atlantic.

Diagnostic features.- Colonial coronate polyps connected by a scyphorhiza; individual tubes with 0-2 cup-shaped internal cusps with secondary cusps on the edge.
Family Nausithoidae Haeckel, 1880

Genus Nausithoe Kölliker, 1853

Nausithoe sp.

References.- Regarding polyp stages of Nausithoe spp. in Brazil: Silveira \& Morandini (1997); Morandini \& Silveira (2001); Horta et al. (2001); Migotto et al. (2002: 22); Morandini et al. (2005: 283-285).

Material examined.- MZUSP 471: Brazil, Ceará State, off Paracuru county (3858’30,7" W, 0258’01,4" S), 43 m depth, 10.xii.1999, one scyphistoma, $70 \%$ ethanol solution preserved, leg. I. Braga, det. A.C. Morandini.

Dimensions. - Total length $=5 \mathrm{~mm}$, diameter at aperture $=$ $0.65 \mathrm{~mm}$, diameter at $2 \mathrm{~mm}=0.5 \mathrm{~mm}$, diameter of basal disk $=0.4 \mathrm{~mm}$, diameter just above the basal disk $=0.2 \mathrm{~mm}$.

Description.- Solitary scyphistoma, with basal disc. Periderm tube light brown at the distal part (aperture), darker basally, cone shaped. Tube surface with many transverse rings, somewhat prominent, with longitudinal striations. Periderm tube $5 \mathrm{~mm}$ long. Periderm tube with inner spines or cusps arranged in 5 distinct whorls of sixteen cusps; 4 large (perradial), 4 intermediate (interradials) and 8 small (adradial). Tube with small attachment disk $0.4 \mathrm{~mm}$ in diameter, $0.2 \mathrm{~mm}$ just above the attachment disk Formquotient (see Jarms et al. 2002) at 2 $\mathrm{mm}$ height 0.25 and at $5 \mathrm{~mm}$ height 0.13 . Scyphistoma growing on calcareous alga.

Systematic remarks.- The specimen presents the typical structure of a solitary Nausithoe species. Specific identification can be only assigned with the study of the medusa stage (Jarms 1991). The morphology and measurements of the specimen suggest that it resembles the polyps of 2 distinct species: Nausithoe aurea Silveira \& Morandini, 1997 and Nausithoe maculata Jarms, 1990. The same conclusion can be drawn from the specimen found by Horta et al. (2001) in southern Brazil.

Distribution.- Nausithoe sp. was reported for the Rio Grande do Sul state (Horta et al. 2001). Nausithoe aurea is, until now, endemic to the Brazilian coast, reported for Bahia, Espírito Santo, Rio de Janeiro, Santa Catarina and São Paulo states (Silveira \& Morandini 1997; Morandini \& Silveira 2001; Morandini et al., 2005). Nausithoe maculata is reported only for Puerto Rico (Jarms 1990). New generic record for Ceará state.

Diagnostic features.- Solitary coronate polyp with characteristic Nausithoidae pattern of tube rings (see Jarms et al. 2002). 
Subclass Discomedusae Haeckel, 1880 - Order

Semaeostomeae L. Agassiz, 1862

Family Pelagiidae Gegenbaur, 1856

Genus Chrysaora Péron \& Lesueur, 1810

Chrysaora lactea Eschscholtz, 1829

Chrysaora lactea Eschscholtz 1829: 81-82; Pl. VII fig. 3. Dactylometra lactea: L. Agassiz 1862: 126. Chrysaora hysoscella: Vannucci 1954: 123-126; Pl. VI figs 1-2. Chrysaora quinquecirrha: Goy 1979: 291. non Chrysaora hysoscella (Linnaeus, 1766). non Chrysaora quinquecirrha (Desor, 1848).

References.-Eschscholtz (1829: 81-82); Oliveira (1950: 369, 389); Vannucci (1954: 123-126; 1957: 594-595); Goy (1979: 291); Mianzan \& Cornelius (1999: 538); Migotto et al. (2002: 23); Morandini et al. (2004); Morandini et al. (2005: 285).

Material examined.- Brazil, Ceará State: 52 young medusae with beginning of gonads, Fortaleza, Meireles beach, 4\% formaldehyde solution preserved, fishing trawl, 1990-1992, leg. H. Matthews-Cascon, det. A.C. Morandini (MZUSP 474, 4 specimens).

Description.- Hemispherical to flattened umbrella, 3-8 cm in diameter (52 examined specimens). Exumbrella covered with minute warts. Twenty-four tentacles, 3 per octant (a central, large one, and 2 smaller secondary ones). Eight rhopalia. Four oral arms with frilled edges, ca. 1.5-2 times bell diameter. Rhopalar stomach pouches a little bit smaller than the tentacular ones. Narrow radial septa widening at the inner end, converging at the outer end with the edge of rhopalar lappets. Some specimens with early development of gonadal tissues. Coloration milky-white and weak pinkish (preserved material).

Systematic remarks.- Taxonomic confusion has occurred regarding some Chrysaora species, because they may reach sexual maturity before all "adult" characters are expressed (e.g. final tentacle number). Chrysaora lactea and $C$. quinquecirrha (Desor, 1848) occur on the Atlantic coast of America; $C$. lactea occurring southern to $C$. quinquecirrha in the continent. Mianzan \& Cornelius (1999) noted a few differences to distinguish the species (the depth of the tentacular clefts, the ending of the radial septa, and the order of appearance of the tertiary tentacles). Morandini et al. (2004) described the life cycle of C. lactea and commented on slight differences in the early development of some species of the genus.

Distribution.- Brazil: From Rio Grande do Sul to Amapá states. Elsewhere: Jamaica and Atlantic coast of South America.

Diagnostic features.- Radial septa with terminal ends wider than rest of septa, tentacular clefts
Order Rhizostomeae Cuvier, 1799

Family Lychnorhizidae Haeckel, 1880

Genus Lychnorhiza Haeckel, 1880

Lychnorhiza lucerna Haeckel, 1880

Lychnorhiza lucerna Haeckel 1880:587-588; Pl. XXXIV figs 1-8.

Cramborhiza flagellata Haeckel 1880: 646.

Lychnorhiza flagellata: Vanhöffen 1888: 29, 42; Pl. II fig. 7, Pl. III figs 1-3.

References.- Haeckel (1880: 587-588, 646); Vannucci (1951: 94-95; 1954: 128; 1957: 594-595); Mianzan \& Cornelius (1999: 545-546); Silveira \& Cornelius (2000: 14-15); Migotto et al. (2002: 23); Morandini et al. (2005: 286-287).

Material examined.- Brazil, Ceará State: 27 medusae with beginning of gonads, Fortaleza, Meireles beach, 4\% formaldehyde solution preserved, fishing trawl, 29.ix.1988, leg. C. Rocha, det. A.C. Morandini (MZUSP 472, 2 specimens).

Description.- Umbrella hemispherical to slightly flat, 3.0-12.5 cm in diameter. Minute warts on exumbrellar surface. Flexible mesoglea. Triangular marginal lappets, with rounded clefts between; 4 inter-rhopalar lappets. Small pointed rhopalar lappets parallel-sided. Eight whitish rhopalia in deep clefts. Continuous subumbrellar musculature. Four pairs of adradial 3winged oral arms, laterally compressed on the base, equal in length to the umbrella diameter. Mouthlets only at the inner surface. Some filaments on the oral arms. Massive oral arm disc, with 4 broad-based pillars, ostia twice the width of pillars. Stomach cruciform, with rounded arms and corners. No central mouth. Ring canal almost $1 / 3$ away from margin. Broad network of anastomosing canals, external to the ring canal. Three to four centripetal blind canals (not reaching the central stomach) between the radial ones. Specimens pale white (long time in preservative).

Systematic remarks.- Endemic species of the southwestern Atlantic. There are 2 other species in the genus, one reported for the Caribbean (Aruba) and the other for the Indian Ocean (India and Indonesia) (Stiasny 1921). Silveira \& Cornelius (2000) described specimens collected in southern Brazil.

Distribution.- Brazil: From Rio Grande do Sul to Amapá states. Elsewhere: Atlantic coast of South America.

Diagnostic features.-Mouth arms without clubs, centripetal blind-end canals not anastomosing, subgenital ostia without papillae. 
Family Mastigiidae Stiasny, 1921

Genus Phyllorhiza L. Agassiz, 1862

Phyllorhiza punctata von Lendenfeld, 1884

Phyllorhiza punctata von Lendenfeld 1884: 296; Pl. IV fig. 1, Pl. V figs 1-4.

Mastigias scintillae Moreira 1961: 6-9; Pl. I fig. 1, PL. II figs 3-4, PL. III figs 5-7, Pl. IV figs 8-12, Pl. V figs 13-14.

References.- Moreira (1961: 5-19); Mianzan \& Cornelius (1999: 544-545); Silveira \& Cornelius (2000: 12-14); Migotto et al. (2002: 23); Morandini et al. (2005: 287-289).

Material examined.- MZUSP 475: Brazil, Ceará State: 1 medusa with beginning of gonads, Fortaleza, Meireles beach, 4\% formaldehyde solution preserved, fishing trawl, 22.x.2003, leg. M.O. Soares, det. M.O. Soares \& A.C. Morandini.

Description.- Hemispherical umbrella, $18 \mathrm{~cm}$ in diameter. Exumbrellar surface with prominent warts. Marginal lappets truncated or pointed, connected by thin membrane. Eight rhopalia (4 perradial and 4 interradial). Circular musculature interrupted over rhopalar canals only at inner part (inside circular canal). Genital ostia oval, twice the width of pillars. Eight J-shaped oral arms with 3 wings (in cross section), with filaments and terminal clubs. Inner wing without mouthlets. Central stomach cruciform, with 8 rhopalar radial canals connected by an internal ring canal. Network of anastomosing canals connecting radial canals externally to ring canal. Another network of anastomosing canals, internal to ring canal, connecting stomach and 4 perradial rhopalar canals. Background color light brown with white warts.

Systematic remarks.- The species was recorded for Brazil during the middle 1950's and was considered a new species (Moreira 1961). Cornelius \& Silveira (1997) suggested that the species was artificially introduced in Brazil; Graham et al. (2003) came to the same conclusion for specimens found in the Gulf of Mexico.

Distribution.- Brazil: Bahia, São Paulo, Paraná states. Elsewhere: Indo-Pacific (Australia, Phillipines, Japan), North Atlantic (Gulf of Mexico), Mediterranean (Israel coast).

Diagnostic features.- Oral arms with clubs, internal network of canals connected with the perradial rhopalar canals.
Family Stomolophidae Haeckel, 1880

Genus Stomolophus L. Agassiz, 1862

Stomolophus meleagris L. Agassiz, 1862

Stomolophus meleagris L. Agassiz 1862: 138, 151; (Agassiz, 1860: Pl. XIV figs 1-8).

Stomolophus agaricus Haeckel 1880: 599.

Stomolophus fritillaria Haeckel 1880: 598; Pl. XXXV figs 1-9.

Stomolophus chunii Vanhöffen 1888: 31, 43; Pl. III figs 4-5, Pl. IV fig. 1.

Stomolophus meleagris fritillaria: Kramp 1955: 165-166.

References.- Vannucci (1954: 126-128; 1957: 594-595); Mianzan \& Cornelius (1999: 547); Migotto et al. (2002: 23); Morandini et al. (2005: 289).

Material examined.- Brazil, Ceará State: 4 young medusae with beginning of gonads, Fortaleza, Meireles beach, 4\% formaldehyde solution preserved, fishing trawl, 1990-1992, leg. H. Matthews-Cascon, det. A.C. Morandini (MZUSP 473, 2 specimens).

Description.- Umbrella more than a hemisphere, 4.0-6.5 $\mathrm{cm}$ in diameter. Smooth exumbrellar surface. Mesoglea thick and rigid. Short and rounded marginal lappets, 20-25 per octant. Pointed rhopalar lappets 2-3 times longer. Eight rhopalia. Subumbrellar musculature broken over radial canals. Short, fused mouth arms, without clubs or filaments. Mouth arms fused with a central mouth, 2 scapulets with mouthlets at base of each mouth arm. Central stomach small. Radial canals connected by anastomosing network, without ring canal. Coloration pale white (preserved material).

Systematic remarks.- Bigelow (1914) suggested that all species of the genus should be considered as $S$. meleagris. Kramp (1955) distinguished the specimens from northern South America as a distinct variety (Stomolophus meleagris fritillaria) based on the maximum size of the medusae, size of scapulets, and number of lappets per octant. The specimens examined agreed with the characters of the 'fritillaria' variety proposed by Kramp (1955).

Distribution.- Brazil: From Rio Grande do Sul to Amapá states. Elsewhere: Atlantic and Pacific coasts of America.

Diagnostic features.- Scapulated rhizostome with central mouth opening, short oral arms without any appendage. 


\section{Acknowledgements}

This work was partially supported by Ministério do Meio Ambiente - ProBio - CNPq (Projeto Institucional 680022/02-3), Fundação de Amparo à Pesquisa do Estado de São Paulo (FAPESP 2001/02626-7, 2003/02432-3, and 2003/ 02433-0), and Pró-Reitoria de Pós-Graduação da Universidade de São Paulo. A.C. Marques has financial support from Conselho Nacional de Desenvolvimento Científico e Tecnológico (CNPq 302596/2003-8).

\section{References}

AGASSIZ, L. 1862. Contributions to the natural history of the United States of America. IV. Second monograph, In five parts, Acalephs in general, Ctenophorae, Discophorae, Hydroidae, homologies of the Radiata. Little, Brown \& Co., Boston.

BIGELOW, H.B. 1914. Note on the medusan genus Stomolophus, from San Diego. Univ. Calif. Publ. Zool. 13:239-241.

CORNELIUS, P.F.S. 1997. Keys to the genera of cubomedusae and scyphomedusae (Cnidaria). In Proceedings of the 6th International Conference on Coelenterate Biology, 1995 (J.C. den Hartog, ed.). Nationaal Natuurhistorisch Museum, Leiden, p.109-122.

CORNELIUS, P.F.S. \& SILVEIRA F.L. DA 1997. Recent observations on the Brazilian scyphomedusa fauna. In COLACMAR VII, Resumos Expandidos, vol. 1. IO-USP, Santos, p.192-194.

ESCHSCHOLTZ, F. 1829. System der Acalephen. Eine ausführliche Beschreibung aller Medusenartigen Strahltiere. Ferdinand Dümmler, Berlin.

GOY, J. 1979. Campagne de la Calypso au large des côtes atlantiques de l’Amérique du Sud (1961-1962) - 35. Méduses. Rés. Scient. Camp. Calypso 11:263-296.

GRAHAM, W.M., MARTIN, D.L., FELDER, D.L., ASPER, V.L. \& PERRY, H.M. 2003. Ecological and economic implications of a tropical jellyfish invader in the Gulf of Mexico. Biol. Inv. 5:53-69.

HAECKEL, E. 1880. Das System der Medusen. I, 2: System der Acraspeden. Gustav Fischer, Jena.

HORTA, P.A., MORANDINI, A.C., BUCCHMANN, F. \& OLIVEIRA, E.C. 2001. Macrobentos do Parcel do Carpinteiro - um desafio para o levantamento da biodiversidade do infralitoral brasileiro. In Anais da XIV Semana Nacional de Oceanografia - Oceanografia e Sociedade: um desafio à teoria e à prática, FURG, Rio Grande, resumo 126.

JARMS, G. 1990. Neubeschreibung dreier Arten der Gattung Nausithoe (Coronata, Scyphozoa) sowie Wiederbeschreibung der Art Nausithoe marginata Kölliker, 1853. Mitt. hamb. zool. Mus. Inst. 87:7-39.
JARMS, G. 1991. Taxonomic characters from the polyp tubes of coronate medusae (Scyphozoa, Coronatae). Hydrobiologia 216-217:463-470.

JARMS, G., MORANDINI, A.C. \& SILVEIRA, F.L. DA 2002. Methods and experiences with cultivating polyps and medusae of Coronatae (Cnidaria, Scyphozoa) with a review of important characters. Helg. Mar. Res. 56:203-210.

KRAMP, P.L. 1955. A revision of Ernst Haeckel's determinations of a collection of medusae belonging to the Zoological Museum of Copenhagen. Deep-Sea Res. 3(Suppl.):149-168.

KRAMP, P.L. 1961. Synopsis of the medusae of the world. J. mar. biol Ass. UK 40:1-469.

LELOUP, E. 1937. Hydropolypes et scyphopolypes recueillis par C. Dawydoff sur les côtes de l'Indochine française. II. Scyphopolypes. Mém. Mus. R. d’Hist. Nat. Belgique 12:59-70.

VON LENDENFELD, R. 1884. The Scyphomedusae of the Southern Hemisphere. Proc. Linn. Soc. New South Wales, 9:155-169, 242-249, 259-306.

MARQUES,A.C., MORANDINIA.C. \& MIGOTTOA.E. 2003. Synopsis of knowledge on Cnidaria Medusozoa from Brazil. Biota Neotrop. 3(2): http://www.biotaneotropica.org.br/v3n2/ pt/abstract?article+BN01203022003 last access in 22/05/2006.

MIANZAN, H.W. \& CORNELIUS, P.F.S. 1999. Cubomedusae and Scyphomedusae. In South Atlantic Zooplankton, vol. 1 (D. Boltovskoy, Ed.). Backhuys Publishers, Leiden, p. 513-559.

MIGOTTO, A.E., MARQUES, A.C., MORANDINI, A.C. \& SILVEIRA, F.L. DA 2002. Checklist of the Cnidaria Medusozoa of Brazil. Biota Neotrop. 2 (1): http:// www.biotaneotropica.org.br/v2n $1 / \mathrm{pt} /$ abstract?article+BN01102012002 last access in 22/05/2006

MILLS, C.E. 2001. Jellyfish blooms: are populations increasing globally in response to changing ocean conditions? Hydrobiologia 451:55-68.

MORANDINI, A.C. 2003. Deep-Sea medusae (Cnidaria: Cubozoa, Hydrozoa and Scyphozoa) from the coast of Bahia (western South Atlantic, Brazil). Mitt. hamb. zool. Mus. Inst. 100:13-25.

MORANDINI, A.C., ASCHER, D., STAMPAR, S.N. \& FERREIRA, J.F.V. 2005. Cubozoa e Scyphozoa (Cnidaria: Medusozoa) de águas costeiras do Brasil. Iheríngia, Sér. Zool. 95:281-294.

MORANDINI, A.C. \& SILVEIRA, F.L. DA 2001. New observations and new record of Nausithoe aurea (Scyphozoa, Coronatae). Pap. Av. Zool. 41:519-527.

MORANDINI, A.C., SILVEIRA, F.L. DA\& JARMS, G. 2004. The life cycle of Chrysaora lactea Eschscholtz, 1829 (Cnidaria, Scyphozoa) with notes on the scyphistoma stage of three other species . Hydrobiologia 530-531:347-354. 
MOREIRA, M.G.B.S. (1961) Sôbre Mastigias scintillae sp.nov. (Scyphomedusae, Rhizostomeae) das costas do Brasil. Bolm Inst. oceanogr., S. Paulo 11:5-30.

MÜLLER, F. 1859. Zwei neue Quallen von Santa Catharina. Tamoya haplonema und quadrumana. Abhand. Naturforsch. Gesellsch. Halle 5:1-12.

OLIVEIRA, L.P.H. 1950. Levantamento biogeográfico da Baía de Guanabara. Mem. Inst. Osw. Cruz 48:363-391.

ORTIZ-CORP'S, E., CUTRESS, C.E. \& CUTRESS, B.M. 1987. Life history of the coronate scyphozoan Linuche unguiculata (Swartz, 1788). Caribb. J. Sci. 23:432-443.

SILVEIRA, F.L. DA \& CORNELIUS, P.F.S. 2000. Novas observações sobre medusas (Cnidaria, Scyphozoa, Rhizostomeae) no Nordeste e Sul do Brasil. Acta Biol. Leopold. 22:9-18.

SILVEIRA, F.L. DA \& MORANDINI A.C. 1997. Nausithoe aurea n. sp. (Scyphozoa, Coronatae, Nausithoidae), a species with two pathways of reproduction after strobilation: sexual and asexual. Contr. Zool. 66:235-246.

SILVEIRA, F.L. DA \& MORANDINI, A.C. 1998a. Asexual reproduction in Linuche unguiculata (Swartz, 1788) (Scyphozoa: Coronatae) by planuloid formation through strobilation and segmentation. Proc. biol. Soc. Wash. 111:781-794.

SILVEIRA, F.L. DA \& MORANDINI, A.C. 1998b. New observations on dormancy mechanisms in Linuche unguiculata (Swartz, 1788) (Scyphozoa: Coronatae). Bol.Mus. Nac., N.S., Zool. 3931-7.

SMITH, A.J. \& MORAIS, J.O. 1984. Estudos preliminares sobre a geologia ambiental costeira do estado do Ceará, nordeste do Brasil. Arq. Ciênc. Mar 23:85-96.

STIASNY, G. 1921. Studien über Rhizostomeen mit besonderer berücksichtigung der Fauna des Malaiischen Archipels nebsteiner revision des Systems. Capita Zool. 1:1-179.

SWARTZ, O. 1788. Medusa unguiculata och Actinia pusilla. Kung. Sv. Vetensk. Akad. Handl. 9:198-202.

VANNUCCI, M. 1951. Hydrozoa e Scyphozoa existents no Instituto Paulista de Oceanografia. I. Bolm Inst. oceanogr., S. Paulo 2:67-98.

VANNUCCI, M. 1954. Hydrozoa e Scyphozoa existentes no Instituto Oceanográfico. II. Bolm Inst. oceanogr., S. Paulo 5:95-149.

VANNUCCI, M. 1957. Distribuição de Scyphozoa nas costas do Brasil. An. Acad. Bras. Ciênc. 29:593-598.

VANHÖFFEN, E. 1888. Untersuchungen über semäostome und rhizostome Medusen. Bibl. Zoologica 1:5-52.
Title: A survey of the Scyphozoa and Cubozoa (Cnidaria, Medusozoa) from the Ceará coast (NE Brazil).

Authors: André Carrara Morandini, Marcelo de Oliveira Soares, Helena Matthews-Cascon \& Antonio Carlos Marques

Biota Neotropica, Vol. 6 ( number 2): 2006

http://www.biotaneotropica.org.br/v6n2/pt/ abstract?inventory+bn01406022006

Date Received 05/06/2005 - Revised 03/15/2006

Accepted 05/01/2006

ISSN 1676-0611 


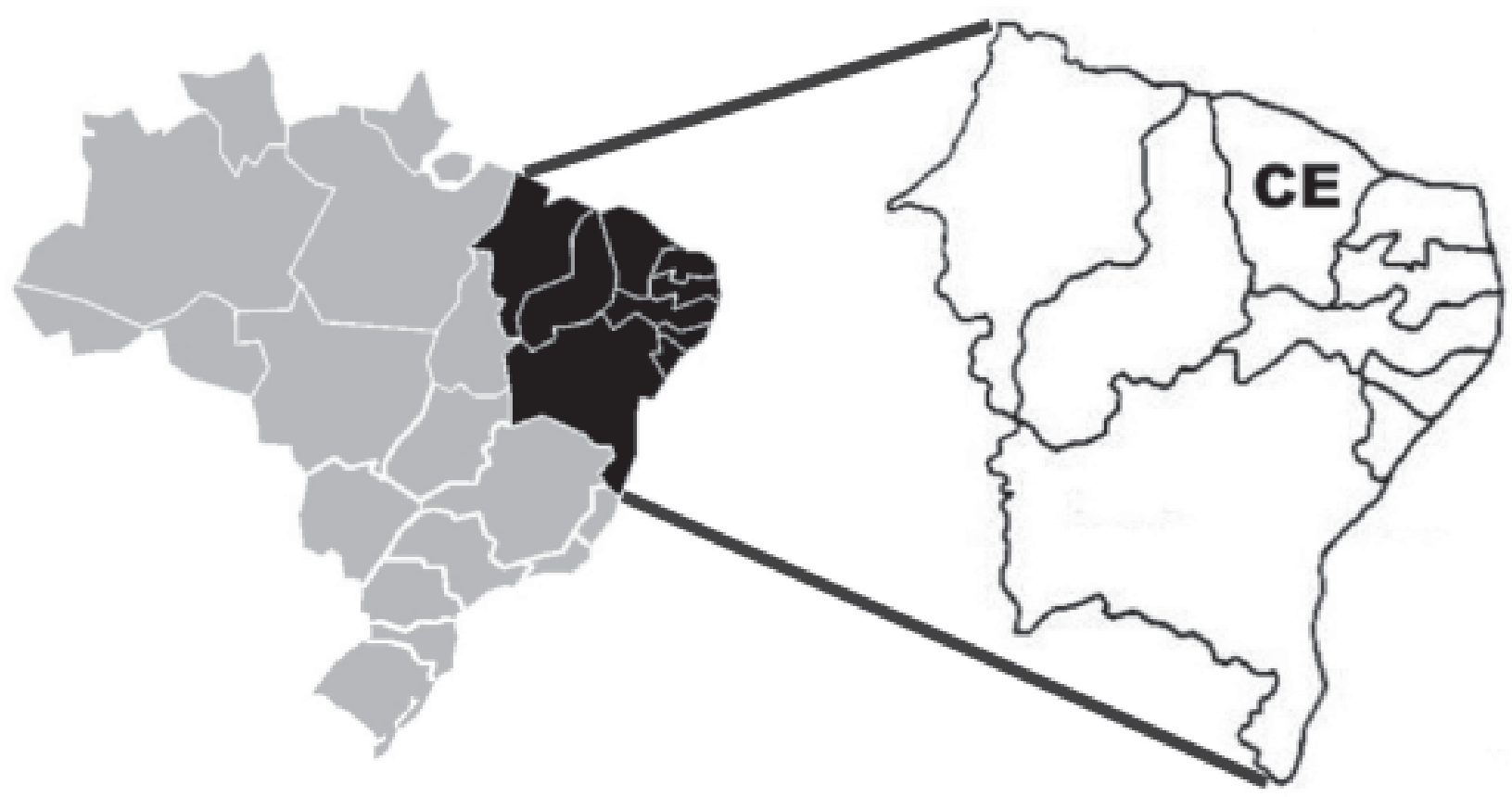

Figure 1. Diagrammatic map of Brazil (left), showing the northeastern region (black). A detail of the northeastern region (right) showing the Ceará state (CE). 